\title{
DWELLING IN THE "DARKNESS ECHOING": The Poetic Vision of Seamus Heaney and Martin Heidegger
}

\begin{abstract}
This essay aims to study Seamus Heaney's vision of poetry, particularly concerning his early oeuvre, in the light of Heidegger's approach to poetic language, memory, and dwelling. A Heideggerian reading of the prominent rural and agrarian sensibility of Heaney's early poems demonstrates how objects and topological features as poetized in his work exceed symbolic representation, and bring forth the aletheia of Being, and how the sense of the unhomely/uncanny in the poet's work serves to gather his community in the same vicinity where co-presencing, letting-be of the other [Gelassenheit], and staying with things assure the unity of the fourfold. The bog, as the principal trope of Heaney's oeuvre, is closely studied, in a cautiously de-politicized context, to reveal a feminine, pre-reflective realm of memory traces, inviting the reader to listen in thoughtful remembrance to the call of Mnemosyne. Thus, Heaney's poetic vision is rendered in terms of an authentic attunement to the maternal-feminine silence of Being, recorded as "rhythm" or the "sound of sense" at the threshold of the pre-linguistic origins of language.
\end{abstract}

\section{Keywords}

Heaney; Heidegger; the Bog; Mnemosyne; The Fourfold

The inevitable presence of Irishness in Heaney's poetry and its varied political ramifications make it relatively difficult to locate his oeuvre in a Heideggerian context. While never decisively siding with any specific faction, Heaney is well aware of the bloody history of his country and, in ways which might not have been quite approved of by Heidegger, the "price" of dwelling, the destructive 
"no" of Being: "Where Heaney's poetry thinks dwelling through to the truth of its ambiguity, Heideggerian Thought calls for a Poetry of the pure 'yes' - without a thought for the terror dwelling within the love" (Garrard 1998: 172). At the height of his career, especially in Seeing Things and The Spirit Level (published in 1991 and 1996, respectively), Heaney was capable of striking a mythopoetic balance, at times self-consciously, between a post-Yeatsean romantic impulse to identify with native topography and a commitment to resolving the poly-genealogical disjunctions of the (post-)colonial Irish identity: "His poetry exhibits a tension between a sense of responsibility to place and a desire for freedom, between the poet holding himself accountable to community and seeking a space free from historical and social ties" (Malone 2000: 1084). However, particularly in Heaney's early poetry, the political dimension is arguably less conspicuous. It could, in fact, be suggested that Heaney's early poetic practice concerns itself more with the Gelassenheit (the "letting-be" of the other, the "releasement" of Being, as opposed to technological "challenging-forth") than the Streit aspect (the "essential strife," the potentially violent ontological "founding" of Being) of the aesthetic experience as delineated in Heidegger's 'The Origin of the Work of Art' (2000).

As with Heidegger's reading of Hölderlin (1996), the aim of the present work is not to "interpret" Heaney's poems in the usual sense: "Heidegger's interpretation is based ... upon a notion of the poetic that seeks to assert the fundamental impossibility of applying objective discourse to a work of art" (de Man 1983: 249). The goal is, rather, to try to communicate a number of "remarks" on his poetry, signs that call our attention and function as pauses for reflection so that we can authentically "attend to" his work: "We must first become attentive to this poetry. Once we have become attentive, we can then 'pay attention to,' that is, retain, some things that, at favorable moments, will perhaps let us 'attend to,' that is, have some intimation of what might be said in the word of this poet" (Heidegger 1996: 1). Such a reading is essentially a form of non-dialectical dialogue which engages with what is left unspoken in the text: "Such interpretation cannot pretend to adequacy, but must render itself questionable, and thus open itself to what the text to be interpreted has to say. Rendering itself questionable, interpretation becomes dialogue" (Harries 1976: 500). Heidegger's central focus is on Hölderlin's hymn 'The Ister' which poetizes rivers; concordantly, we have selected Heaney's series of Bog Poems and 'Personal Helicon' (1966 / 1998: 15 ) as the fulcrum of our study, as poems that poetize and celebrate a variety of geopoetic features, including wells and bogs. This study is strongly informed by Heaney's early poetry in general, reading his oeuvre, admittedly in a less overtly political manner than most other critics, in the light of a Heideggerian approach to poetic language, memory, and dwelling.

Heaney's poetry shares a unique agrarian sensibility with Heidegger. Heidegger's choice of Van Gogh's painting of a farmer's shoes as the subject of his phenomenological argument concerning the essence of art, his use of "the earth" to name the self-secluding and inexhaustible nature of Being, and the forestry 
terminology he occasionally employs (such as Holzweg and Lichtung) are just a few examples of his enduring preoccupation with rural life and its spiritual dimension. In the same vein, as Garrard explains, "Heaney has always been attentive to dwelling as a call to poetry. His native land is a mnemonic: we are reminded of personal, tribal memories by features of the landscape" (1998: 170) such as bogs, peat-turfs, potato-drills, springs, wells, etc. Moreover, ordinary objects of memory, chiefly work-tools such as the spade, the pumping well, and the bucket, are invested with a symbolic or spiritual aura, although Heaney is most often careful to "justify their aura through a close and down-to-earth association with childhood and home" (Regan 2014: 321). The poet meditates authentically on the thingliness of things, and becomes attuned to that which, in even the commonest of objects, eludes intelligibility and exceeds the world of meanings: "The unpretentious thing evades thought most stubbornly. Or can it be that this selfrefusal of the mere thing, this self-contained independence, belongs precisely to the nature of the thing?" (Heidegger 2000: 85). The thing in Heaney's poetry is not to be understood in terms of standard metaphysical conceptions "as a bearer of traits, as the unity of a manifold of sensations, as formed matter" (85). Rather, it could be argued that the poet personally engages with the mysteries of the thing, and encounters it not as an external object to be described by an isolated subject reflectively aware of it, but as one integrally involved with it on a practical level, so that "the equipmentality of equipment" [Zeughaften des Zeuges] (88) is revealed. The hammering anvil in 'The Forge' (1969 / 1998) "horned as a unicorn", for instance, becomes "an altar / Where he expends himself in shape and music" (Heaney 1998: 19) linking the aesthetic appeal of the object, the blacksmith's practical engagement with it as an equipment, and the process of poetic creativity. This unitary mode of understanding is anterior to cognition, and belongs to a more primordial level of experience in which Dasein as Beingin-the-world [In-der-Welt-sein] tends to be inseparable from the world in which it essentially dwells. Heaney's phenomenological descriptions of things provide the reader with a poetic medium for thinking that which is worthiest of thought, Being itself: a pre-reflective, trans-metaphysical thinking on Being [Das Denken des Seins] which involves the soil feeding the metaphysical roots of the Cartesian tree of philosophy.

Heaney's childhood observations of natural features and domestic objects, and the poetic inspirations he derived from them in the process of his double maturation as both an individual and a poet, documented throughout his first volume Death of a Naturalist (1966 / 1998), can be summed up in a phrase he uses in the closing poem of that volume, appropriately titled 'Personal Helicon': "to pry into roots" (1966 / 1998: 15). The term "roots" has a multiplicitous significance for Heaney. On the literal level of sense-impressions, the poet exquisitely records olfactory and tactile encounters with the vegetative side of nature through sound effects, for instance via alliteration in "the smells / Of waterweed, fungus and dank moss" (15). This palpable materiality, on the other hand, is always imbued or compounded with the metaphysical, more metaphorical, suggestions of 
natural objects, particularly on the memorial level: "they also function emblematically and symbolically as traces of a former life, as remainders and reminders of human endeavor" (Regan 2014: 320). Speaking of familial roots, the maturing Heaney strives to write poetry the way his father and grandfather "could handle a spade" (Heaney 1998: 3) - family elders whom the would-be poet used to watch digging and turf-cutting in the field. Heaney, as a child, absorbed all kinds of sensuous material from this agrarian family tableau, ranging from the "clean rasping sound" of the spade to the "cool hardness" of the newly-scattered potatoes (3). Memory, tradition, and poetic craft intermingle with the rich physicality of the "living roots" (4) and constellate around the word "rhythm" (3).

Intimately linked to the imagery of "roots" in Heaney's poetic world is the similarly polysemic trope of the "bog." Anthony Purdy uses the term "mnemotope" (à la the Bakhtinian "chronotope") to describe the bog-bodies, the Iron-Age human bodies perfectly preserved inside the peat: The Bog Poems, such as 'The Tollund Man' (1972 / 1998) and 'The Grauballe Man' (1975 / 1998), "speak of a life anchored in an everyday that was then but is also now" and "allow us to see time" (2002: 94). As Garrard points out, the bog as mnemotope has the quality of "exceeding representation (the land as memorative text), in that the past is actually preserved": the bogland is "not only a provocation to memory, but operates as memory itself, thus assuming a remarkable literal-figural role" (1998: 170) accentuated by the excavation of the often-sacrificial bog-bodies. In this capacity, the "bog" functions like W. B. Yeats's use of the "tower," a multidimensional trope as well as an actual structure in Ireland (Thoor Ballylee), owned by the poet, whose particular features and surroundings participate in the poet's symbolic imageries, blending Irishness with English Romanticism, the actual with the metaphorical. This ambi-valence of tropes, to varying degrees and in different memorial contexts, applies to many other elements in Heaney's poetry, such as wells and springs, and enables the poet to "poetize," rather than merely compose, just like Hölderlin poetizes the essence of the rivers in his hymnal poetry. The bog is, accordingly, not a symbolic image in the metaphysical sense, an aesthetic representation which separates the sensuous from the non-sensuous [das Nichtsinnliche]: it does not objectify language by subordinating the former to the latter [Sinnbild]. Thus, the bog is not a mere container of a higher or deeper spiritual content in the allegorical mode, "a proclamation of something else by way of something, namely, by way of something familiar that can be experienced sensuously" (Heidegger 1996: 15).

What the bog does, its function or significance, cannot be grasped in terms of a metaphysically-grounded scientific knowledge that the reader, with a certain subjective distance, may attain through reflective interpretation. It is an "enigma" [Rätsel] that is not meant to be solved, but to be given counsel to and cared for, in the sense of "thoughtful remembrance" [Andenken]: "We must try to bring the enigma as enigma closer to us" (Heidegger 1996: 35), that is, to unveil its concealment. The bog as a literary figure is a medium for the poetic aletheia of the enigma of Being. This is due to the fact that language, that is, poetry in 
the essential sense, "by naming beings for the first time, first brings beings to word and to appearance. Only this naming nominates beings to their being from out of their being" (Heidegger 2000: 98). Words are not linguistic objects functioning as representations of things, but the site where the thingness of things is unconcealed in the same event of Being [Ereignis] in which the poetic essence of language (the wordness of the word, as it were) is concealed. Poetry is the projection of the Light of Being, "the saying of the unconcealedness of what is" (98) in "the sunlit absence" (Heaney 1998: 93) of beings. Thus, language, in the authentic or poetic sense, is closely bound up with Being itself: it is not present as an object or entity, but "effects an ontico-ontological difference in that it is through language that things stand revealed in their being" (Clark 1986: 1010). In other words, poetic "language appropriates or 'brings into nearness' through a structure of non-apparent withdrawal" (1010) brought into the Open only as its essential self-seclusion - the word "attains its proper effulgence" (Heaney 1980: 48 ) in poetizing the essence of the thing. The same aletheiac structure inheres "within" literary images (which, in traditional metaphysical terms, are supposed to image, portray, imitate, re-present, or mirror particular phenomena, one thing standing for another). What we see in the poetic mirror is not a mere image (reflection) of, as an example, a "stone" placed before the glass, but the "stone" in its unconcealed thingness; on the other hand, the word "stone" is itself the actual object standing revealed in its being through the medium of language. The two aletheiac structures, mirroring each other through poiesis, form a "fold" [pli], single in its doubleness - a Mallarméan term adopted by Derrida in "The Double Session' where he locates it "between present acts that don't take place. What takes place is only the entre, the place, the spacing, which is nothing" (Derrida 1981: 214).

In the same spirit as digging, the bog changes the focus of the poet's approach to loco-descriptive features from topography to archeology, from the horizontal to the vertical, from temporal sequentiality to spatial extension, offering itself as a glacier of time, a "floe of history" (Heaney 1998: 121). "A perfect simulacrum" of Heaney's poetry, the continually crusting bog gathers "the endless layers of Irish history" in itself, in the very poem, "in the word itself - almost any word, which is a palimpsest, a story of erasures that underlie the current writing" (Parini 2018: n.p.). The word and the thing, sharply separated by metaphysical modes of representation, are brought closer again even as a more primordial form of language is being metaphorically excavated, a language of shape: "Kinned by hieroglyphic / peat on a spreadfield" (Heaney 1998: 120) to the 'Bog Queen' whose "body was braille / for the creeping influences" (112), the poet is prepared to "step through origins" (120). On the one hand, what the bog yields, "surfacing with a touch of mystery" (1988: 34), fascinates Heaney in its unique access to a communal past, and its being an actual relic of history to identify with: "I love this turf-face, / its black incisions, / the cooped secrets / of process and ritual" (1998: 120). On the other hand, this fond memory of field-work is inseparable from the long history of tribal violence and the casualties of nationalist mythology, 
specifically the Troubles since 1969. At certain points in the Bog Poems, Nerthus the bog goddess appears to be one and the same as Cathleen ni Houlihan, the Mother-Ireland figure: the narrative voices "stand at the edge of centuries" (1998: 123) and bear witness to how the peat is stained "with the blood / of her faithful" (125) and "the inhumed faces / of casualty and victim" (125); how the "love-nest is disturbed" (122) by political and historical realities; how the "insatiable bride" (121) personifying the bog has swallowed so many of her kin; and how they have shared the "tribe's complicity" (156) to "cast the stones of silence" (118) at the "poor scapegoat" (118). These scapegoats, whether bog-bodies sacrificed in pagan rituals or Irish women "cauled in tar" (118) as part of their punishment for consorting with British men, are sacred/anathematized figures included in the community only as necessary exclusions from that community, exiles whose banishment is the very condition of legitimation for the Law that has banished them (Garrard 1998). This is the Agambenian paradox of being beyond the Law while remaining within the confines of the same Law, which would ironically render the scapegoat un-touchable even by the ravages of time. This uncanny timelessness, compounding the ideological concerns, is "part of the horror of the bog bodies": "Existing outside the normal passing of time, the bodies bring with them their own radically different internal historicity, which disrupts the sense of continuity, the historicity of the present" (MacKay 2009: 83).

Heaney's ambiguous position toward national consciousness has been interpreted as vigilant pacifism or a deconstruction of the radically divided Irish political atmosphere. ${ }^{1}$ He does not choose a definitive place in "the contextual binary oppositions of nationalist-unionist; republican-loyalist; Catholic-Protestant or, at a broader level, poetry-politics and the tongue being governed as opposed to being self-governing"; rather, he engages in "reconstituting the whole structure in order to redefine the role of the poetic text within the political context" (O'Brien 2003: 99). In short, Heaney's post-Yeatsean "centre holds" (Heaney 1998: 123) although "nothing will suffice" (125). The poet seems to be well aware of his uncertainties and how they leave him exposed and vulnerable. In the pivotal poem 'Exposure' (1975 / 1998) Heaney confronts his own self-doubts ("I sit weighing and weighing / My responsible tristia" [1998: 143]) and the guilt he feels for leaving the center of the sectarian and political conflict in Northern Ireland. The poem is set in an autumnal landscape, rainy and attended by the "last light" (143) of the year or of the day approaching sunset. The dejection (tristitia) engulfing the bleak December backdrop and the desperate poet is relieved as each rain-drop "recalls // The diamond absolutes" (144). The raindrop receives the dying light and reflects back within itself the uni-verse as a poetic microcosm, reminding Heaney with pure clarity of who he is: "I am neither internee nor informer; / An inner émigré" (144). Heaney will "keep striking / Inwards and downwards" (42): the bog is the dynamic milieu where the unity of Heaney's art is made possible in the sustaining of the politico-poetic tension between distinct yet intimate layers of the bog. This is what Heidegger calls "the fighting of the battle" between the world and the earth, "the continually self-overreaching gathering of the work's 
agitation. The repose of the work that rests in itself thus has its presencing in the intimacy of striving" (Heidegger 2000: 93). But the refusal to get actively involved in the struggle, at the height of political radicalism, and instead "Taking protective colouring / From bole and bark" (Heaney 1998: 144), tends admittedly to deflate the Streit aspect of Heaney's poetic thought and the destructive potential of the more conspicuous "comet's pulsing rose" (144) with its "million tons of light" (143). Heaney's retreat is not a military strategy, but at most a passive involvement as detachment: the poet seems to be identifying with the bog-body itself, its "desolate peace" (125), its "sad freedom" (65), with a melancholy tone of pre-reflective sympathy. The spectacular elegy 'Casualty' (1979 / 1998) leaves the reader with a sense, not of tribal self-deprecation or historical consciousness, but of the individual "freedom" Heaney has tasted with the fisherman as his subject: "To get out early, haul / Steadily off the bottom, / Dispraise the catch, and smile / As you find a rhythm / Working you, slow mile by mile, / Into your proper haunt / Somewhere, well out, beyond..." (157).

This is why it could be claimed that the often-quoted lines "I grew out of all this / like a weeping willow / inclined to / the appetites of gravity" (123-124) from 'Kinship' (1975 / 1998) reveal a deep feminine sensibility which supersedes the Bog Poems' political contextualization and their invocations of the arbitrariness of history, the post/colonial ambivalences of the poet-figure, and possible phallic interpretations of digging in the feminized landscape. It is, on the contrary, tempting to suggest that the stanza calls attention, first and foremost, to the ecstatic essence of Dasein, ek-stasis - standing out towards the openness of Being. The transcendence of Dasein, what a later Heidegger more accurately names standing-in or instancy [Inständigkeit], has its origin in Being itself: the calling of Dasein is itself called by that which can only come of its own accord (in unconcealment). This indwelling in Being, which simultaneously reveals Dasein's finitude, is a burdensome task, like that of a farmer digging with her spade or a poet digging with his "squat pen" (Heaney 1998: 4): the authentic Dasein must think of "standing in the openness of Being, of enduring and outstanding this standingin (care), and of out-braving the utmost (Being toward death)" (Heidegger 1956: 214). The melancholy posture of the weeping willow, the tree "grown long-haired and thoughtful" (Heaney 1998: 144) is already one of "inclination" toward the earth, a supplement to the fact that all things on earth, including the willow, are naturally inclined towards the earth owing to its superior mass. Since the source of this attraction, the gravity, is physical mass, all things are essentially already "gravitational" entities, together setting forth a whole draft/drawing of attractions [ganzen Bezuges der Anziehung]. The weeping willow presents the effect of gravity, its presence as a force of nature, on a visual level. However, the willow does not "portray" that which is defined in language as "gravity" in a re-presentational manner, doubling the phenomenon in the literary image; rather, through the aletheiac fold of poetic language discussed above, "something single, in becoming double through the mirror [of the literary image] is revealed more truly in its nature (Wesen). The image is no longer a doubling but is in a peculiar way 
originary" (Clark 1986: 1012-13). Gravity, "in the truth of its nature" (Heidegger 1971: 169) is the weeping willow.

The mimetic relation of "gravity" to "Being" adds a tertiary layer to the aletheiac fold of the poiesis at work in this stanza. In 'What Are Poets for?' Heidegger discusses gravity in relation to Being in his complex reading of the last lines of one of Rilke's poems (Heidegger 2001: 89-139). The issue at hand is the human will to will, and Heidegger's distinction between the self-assertive human being of the age of technology who "opposes himself to the Open" by "parting against" it (113) and those few possessing a stronger and different kind of will who "reach sooner into the abyss" (115), and venture beyond the shield of Being into the vulnerability of the nothing. This corresponds to Heaney's distinction in 'From the Canton of Expectation' between "this generation born impervious to / the triumph in our cries of de profundis" and "the guardian angel of passivity ... who stood his ground in the indicative", between imperative demands of the new age latecomers and "faith in winning by enduring most" (Heaney 1998: 320). The latter "answer sooner to Being that shows itself as will" (Heidegger 2001: 116) and are capable of converting "unshieldedness as such into the Open and transmuting it into the heart's space of the invisible" (133). In Rilke's words, "There, outside all caring, / this creates for us a safety - just there, / where the pure forces' gravity rules" (97), the shelter provided for us only by the most daring. Such a being, namely the poet, will be the bringer of "salvation" [die Rettung] in the age of degodification [Entgötterung], a salvation which "must come from where there is a turn with mortals in their nature" (115-116). Heidegger names this being the Angel [Engel], a basic word in Rilke's Duino Elegies. The Angel, the messenger and annunciator of Being, "is in being by virtue of the stilled repose of the balanced oneness of the two realms within the world's inner space" (132), that is, the visible and the invisible. Rilke writes: “... in the end, / it is our unshieldedness on which we depend, / and that, when we saw it threaten, we turned it / so into the Open that, in widest orbit somewhere, / where the Law touches us, we may affirm it" (97). Heidegger elucidates the "widest orbit" here in relation to another one of Rilke's peculiar phrases, the "globe of Being" [Kugel des Seines]:

The globe of Being of which he speaks here, that is, the globe of all beings as a whole, is the Open, as the pure forces serried, boundlessly flowing into one another and thus acting toward one another. The widest orbit is the wholeness of the whole draft of attraction. To this widest circle there corresponds as the strongest center, the "unheard-of center" of pure gravity. $(121-122)$

The angelic poet, the "I" in Heaney's stanza, is the being who alone lets this dark, unheard-of, and inarticulable center of gravity of the widest orbit appear in its unconcealing-illuminating union of all things.

The memorial significance of the bog is arguably one of the most prominent sides of Heaney's poetry. Rather than offering direct access to the past itself in its entirety (a finished past) the bog presents a memorative palimpsest, an ar- 
chive of half-erased traces and overwritten recollections, layer "camped on" layer (Heaney 1998: 42): "Far from being perfectible, memory in these poems is an ongoing process, constantly revisiting the same events from different perspectives, and constantly revising itself" (MacKay 2009: 80). The reason for this is the inevitable intertwining of the present world of the remembering subject (the context of his own experiences) and the past that is being remembered. In other words, "the person remembering is in some way entering into the unknown; it is not an archaeological process of revealing discrete or complete memories or engrams, but rather a creative or interpretative process of narrating engrams in terms of the context of retrieval" (83-84). The bog may be thought of as a pure or immemorial past, a "bottomless" (Heaney 1998: 42) reservoir of all events, that can never become fully present and has never been anybody's present. It is a forever self-secluding past, beyond consciously-accessible memory, independent from and anterior to the present while paradoxically maintaining a close relation to it since this past inevitably participates in the constitution of the present. In this manner, the bog is the precondition for all reproducibility, above and beyond the limits of Irish history. Seamus Heaney the poet is already part of the bog. On the one hand, by continuing to re-write and re-find himself, "striking / Inwards and downwards" (Heaney 1998: 42) in the palimpsestic bog, he keeps attending to the inexhaustible nothing, seeking after recollections, penetrating the pure past, asking questions, and worlding the bog (the Streit aspect of the authentic experience of Dasein). On the other hand, by continuing to deify "the hearth-feeder" (124) and bask in the "sunlit absence" (93) of the farm, he keeps being attuned to the feminine primordiality of Being, preserving the treasure of the pure past, confirming the passive presence of "the invisible, untoppled omphalos" (19) in its vibrant dormancy, sacral aura, and protective function (Schmidt 1985: 205-208), and appreciating his havingbeen-ness [Gewesenheit] as already being-in a community defined by a common destiny of guilt and resolution (the Gelassenheit aspect). The twin incarnation of the poet's involvement with the bogland of the pure past can be formulated as the psychical order of Eros-Mnemosyne, the empirical structure of contiguity and resemblance, of ecstasy and epiphany, introduced by Deleuze, prior to his discussion of the third synthesis of time (1994: 85). Deleuze elaborates that Mnemosyne, as the ontological dimension of memory, embodies the paradox of "the virginal repetition" of difference: "beyond the lover and beyond the mother, coexistent with the one and contemporary with the other, lies the never-lived reality of the Virgin" (85). In 'Bog Queen' Heaney writes: "a slimy birth-cord / of bog, had been cut / and I rose from the dark" (1998: 114). Unlike the mythological goddess, however, the authentic poet restores and shelters the forgotten umbilical attachment to the proto-maternal bog: all he knows is "a door into the dark" (19) but he does not go through it, at least not in Heaney's early phase, but persists at the thresholds of life like Eurydice's apparition, constantly emerging and fading, inhabiting the eternal echoes of Orphic elegies - a theme we will return to at the end of the article. 
While the impact of Romanticism on his oeuvre, though less vigorous than the influence on Yeats, ${ }^{2}$ should not go unnoticed, Heaney's poetic self-knowledge may not be properly conceived of as the end-product of a subjective reflection on particular natural settings (that is, a supra-natural insight or vision captured in the so-called Greater Romantic lyric): such thinking is but a forgetfulness of Being [Seinsvergessenheit], the lethe of aletheia. Heaney's poetic thinking is, it could be maintained, more in line with a Heideggerian, trans-metaphysical, recollection of the Unthought, that is, of Being as such. Heidegger's etymo-mythological understanding of memory in What Is Called Thinking? (1968) revives its feminine and pre-reflective origins as the source of poetry, interlinking the myth of Mnemosyne as the Greek goddess of Memory, the role of the mother as the birth-giver and nurturer and protector, and an alternative German translation of the word Mnemosyne ["Memory"] not as the neutral das Gedächtnis but as the feminine die Gedächtnis:

Mnemosyne, daughter of Heaven and Earth, bride of Zeus, in nine nights becomes the mother of the nine Muses. Drama and music, dance and poetry are of the womb of Mnemosyne, Dame Memory. It is plain that the word means something else than merely the psychologically demonstrable ability to retain a mental representation, an idea, of something which is past. Memory -from Latin memor, mindful- has in mind something that is in the mind, thought. But when it is the name of the Mother of the Muses, "Memory" does not mean just any thought of anything that can be thought. Memory is the gathering and convergence of thought upon what everywhere demands to be thought about first of all. Memory is the gathering of recollection, thinking back. It safely keeps and keeps concealed within it that to which at each given time thought must be given before all else, in everything that essentially is, everything that appeals to us as what has being and has been in being. Memory, Mother of the Muses - the thinking back of what is to be thought is the source and ground of poesy. This is why poesy is the water that at times flows backward toward the source, toward thinking as a thinking back, a recollection. Surely, as long as we take the view that logic gives us any information about what thinking is, we shall never be able to think how much all poesy rests upon thinking back, recollection. Poetry wells up only from devoted thought thinking back, recollecting. (1968: 11)

Feminine elements, earth and water in their multiple manifestations, permeate Heaney's poetry, as the images aspire toward an often deflated sense of the ritual or the mystical: soil, rain, sea, wells, springs, rocks, bogs (and the rites of Nerthus, the fertility goddess of the bogs), Antaeus son of Gaia (the Mother Earth goddess of Greek mythology), the ring, the womb, the moon ("The moon's host elevated // in a monstrance of holly trees" [1972: 9-10] ; "sure as the satellite's / insinuating pull / in the ocean" [1998: 29]), icicle ("Keep your eye clear / as the bleb of the icicle" [101]; "Against / ebb, current, rock, rapids, / a muscled icicle / that melts itself longer / and fatter" [29]), stalagmite ("Constant ablutions, / Such drowning love / Stun a stake // To stalagmite" [27]), snow ("Snowdrops / And candles soothed the bedside" [12]), arctic features ("aurora borealis ... but 
no cascade of light" [101]; "before the nails were sunk / and the black glacier / of each funeral / pushed away" [97]), etc. If the Pre-Raphaelites and Shelley, to a great extent, shaped Yeats's sensibility (Watson 2006), Heaney's was formed, in his own words, by "the dolorous murmurings of the rosary, and the general Marian quality of devotion. The reality that was addressed was maternal, and the posture was one of supplication" (quoted in Longley 1992: 53). Heaney is addressing the maternal aspect of Irish Catholicism: "In practice, shrines, the rosary beads, all the devotions were centred towards a feminine presence" (53).

This feminine sensibility tends to lend the stereotype of Irish poetic melancholy, inherited from Yeats, an original, less heroic and more down-to-earth, color. This unique elegiac tone is palpable everywhere in Heaney's poetry, as in the notable sonnet cycle Clearances (Heaney 1998: 306-314) where he commemorates his mother's death. In the final sonnet of the sequence Heaney links the loss of his mother to the cutting down of a chestnut tree, a process vividly recorded in his poetic imagination: "I heard the hatchet's differentiated / Accurate cut, the crack, the sigh / And collapse of what luxuriated / Through the shocked tips and wreckage of it all" (314). Both losses have left "a space / Utterly empty, utterly a source" (314) and the sonnet ends with what, it could be claimed, are some of the most essentially Heideggerian lines in his poetry: "Its heft and hush become a bright nowhere, / A soul ramifying and forever / Silent, beyond silence listened for" (314). The phrase "bright nowhere" vividly captures what Heidegger names clearing/lighting [Lichtung] or the Open. The path of the philosopher is a dis/ orderly forest-path or woodway [Holzweg], a searching that does not project in advance a particular destination, but a seeking which belongs to finding since one has already found that which is being sought. The authentic thinker starts walking on this path-to-nowhere until he reaches a "clearing", that is, an area of land within a wood or forest devoid of trees. The unexpected revelation of this nothing amid the whole of beings is an access to the Open where the Being of beings is unconcealed: "a clearing redirects our attention from entities to being, that usually unnoticed ontological light through which things ordinarily appear. Seeing differently, Heidegger thus suggests, can turn an apparent dead-end into the occasion for an ontological epiphany" (Thomson 2015: n.p.). Thus, the void the chestnut tree as well as Heaney's mother has left behind is both an empty space and a source, the sudden dis-appearance of beings as a whole into the nothing and their being brought into the Open where the Light of Being, the primal essence of the $\mathrm{m} /$ other, sheds light on and lays bare the being of beings as unconcealment, upon the fiat lux of a pre-linguistic, feminine no-where of pure silence. In his essay 'A Placeless Heaven' Heaney calls this void "luminous emptiness": "In my mind's eye I saw it as a kind of luminous emptiness, a warp and waver of light, and once again, in a way that I find hard to define, I began to identify with that space just as years before I had identified with the young tree" (1988: 3-4). The source of this ever-living, aletheiac fire is the originary soul, and the poet ("I") is the Beseeler, the en-souler or the soul-giver who, being consumed in the same fire and almost turned to ashes, insufflates the soul into beings presencing together through the 
poet's saying. Derrida, invoking Heidegger's reading of Schelling concerning spirit [Geist $]$ as unity and gathering, and considering the fact that for Schelling love as the Most High is greater than spirit (the breath of love) and prior to the separation of ground and existent (hence, the origin of language), explains: "The soul is here the synonym, an 'other word' for 'Mut' or 'Gemüt.' Gemüt is not spirit, but the poet's Gemüt receives, lodges spirit, it gives place in him to the welcoming of spirit, of Geist - coming or coming back [revenant] in him" (78). (Notable here is the similarity of the word Mut to Mutter, the German word for mother).

Heaney's word "ramifying" calls attention to the inexhaustible dimension of intelligibility, what Heidegger names "earth", the self-withholding abyss $[A b-$ grund] that no amount of "digging" ("worlding") can conquer. This grounding of the world on the earth, as with the Greek Temple in 'The Origin of the Work of Art', "first fits together and at the same time gathers around itself the unity of those paths and relations in which birth and death, disaster and blessing, victory and disgrace, endurance and decline acquire the shape of destiny for human being" (Heidegger 2000: 89). Great art-works make this historical revolution possible: the illuminating-uniting void left by the poet's mother, it could be maintained, is a primordial source for Heaney's own epoch-making masterpieces. Furthermore, our hermeneutic engagement with poetic texts in order to produce as many genuine interpretations as possible is an open-ended struggle to world the earth. This includes tracing the presence of the maternal void in the rest of the sonnets from Clearances: "The dead mother ramifies, branching into the people and texts that remember her. As in the traditional elegiac coda, Heaney glances back over the work of his sequence, which has attempted to replant the lost mother in words that germinate multiple readings. Thus, the ending branches into divergent meanings" (Ramazani 1994: 358).

In the final sonnet of Clearances, Heaney depicts the soul as eternally silent, a silence that may be read as that of the permanently self-secluding Being. On the other hand, the closing line of the same sonnet, "beyond silence listened for" (Heaney 1998: 314), renders the nature of such silence ambiguous, both lexically and conceptually: Ramazani lists a number of possible interpretations of this line (1994: 358). In the posthumously-published text known as Beiträge (2012) Heidegger asserts that our task as late-comers in the age of ungodding is to listen to the silence of Being. Now, "listening for silence" would be a representational objectification of that silence as a prize to be won by a reflective subject: we have to venture "beyond silence listened for." Heidegger suggests that the singular way to listen to this silence (corresponding to a non-subjective manner of thinking) is the grounding attunement of restraint/reticence [Verhaltenheit], an eloquent silence on our own part, a becoming silent in and for a pre-reflective, originary language responsive to the silence of Being and protective of its self-withholding truth: "the sheltering of truth will leave concealed what is most concealed and will thus lend it a unique presence" (2012: 317). This poetic silence addresses and replies, a speaking which belongs to being spoken to, a letting oneself be said which makes possible the coming of Being into the Said (Heidegger 1971). 
Hence, the poetizing poet's "crucial action is pre-verbal, to be able to allow the first alertness or come-hither, sensed in a blurred or incomplete way, to dilate and approach as a thought or a theme or a phrase" (Heaney 1980: 49). This is the sigetic language of silence and secret, which grounds speech:

In his will to penetrate the mystery of language, Heidegger discovers another name that is more appropriate because it gathers together in a single word logos and Being, the Saying and the Said, and that which induces us to speak. He calls it "die Sage" (Saying), from an ancient word that has the same origin as deixis, the source of signs that are not made from the gestures of humans, but rather from the "gesture of the word". (Kelkel et al. 1997: 395-396)

Heaney's elegiac tone is prominent not only in his later (pointedly gendered) figurations of parental loss, as in The Haw Lantern and Seeing Things (published in 1987 and 1991, respectively), but also, right from the start of his career, in renderings of the very experience of maturation and awakening which involves interwoven revelations of the darker side of nature, of the inextricable memory of tribal violence, and of the peculiar burdens of poetic composition - a triptych of Heaney-in-the-making. The pre-adolescent Seamus, obsessed with local landscape, meets (his own) nature's retributive and traumatizing aspect in Heaney's first volume of poetry: the "obscene threats" of "the great slime kings" emerging from the frogspawn, "gathered there for vengeance" in 'Death of a Naturalist' (1998: 5-6), the catalogue of phobias in the windowless 'Barn' where "The dark gulfed like a roof-space" (7), the injustice of decay and transience portrayed in the childhood habit of 'Blackberry-Picking' always being spoiled when "the sweet flesh" of the fermented and fungus-infected fruit "would turn sour" (8), the inevitability of senescence rendered in 'Follower' reversing the roles in the father-son relationship (11), and the abject reality of death presented in 'Midterm Break' as the "four-foot box" holding the corpse of his four-year-old brother (12). All of a sudden, the would-be poet's world becomes alien, radically other than ordinary, on the natural, topographical level.

This feeling of alienation from and towards one's own immediate world, this singular manifold of the fearful, the powerful, and the inhabitual, originates from the fact that "that which is their own often remains foreign to human beings for a long time, because they abandon it without having appropriated it. And human beings abandon what is their own because it is what most threatens to overwhelm them" (Heidegger 1996: 21). Heidegger adopts the poetic Greek word $\delta \varepsilon \imath v o ́ v$ [deinon] in his reading of Sophocles' Antigone (51-74), and considers its various translations, ultimately opting for the "uncanny" [unheimlich] and the "unhomely" [unheimlisch]. The unhomely is always present in the homely, and is the ground of human beings: becoming homely, "to dwell in what is one's own" (21) is what is most difficult for human beings. Man feels "lost, / Unhappy and at home" (Heaney 1998: 65).

That which can make the becoming-homely of human beings possible is what determines the locality of the homely, what "determines them to where they 
belong and where they are homely" and "thus brings human beings into their own and maintains them in what is their own" (Heidegger 1996: 21). In the case of Heaney, it is most essentially the native farmland, with its wells, springs and potato-rills, or the more collective phenomenon of the peat-bog. The bog is "the locality that pervades the abode" (21) of those whose dwelling appropriates this abode as abiding. The abode is a "whiling" in which we find an active "rest" "a grounded repose in the steadfastness of one's own essence. In rest, the human essence is preserved in its inviolability" (20). In this respect, Heidegger finds in the word $\pi \dot{\varepsilon} \lambda \varepsilon v v$ [pelein] and its derivatives a similar interlinkage of authentic dwelling and the aletheia of Being, of Eros and Mnemosyne, of Streit and Gelassenheit. $\pi \dot{\varepsilon} \lambda \varepsilon v v$ variously means to stir, to come forth of its own accord, to come into presence, to find and abide in one's own locale and site, to abide amid change and becoming, the concealed presencing of stillness and tranquility amid constant and unconcealed absencing and presencing, that is, amid the appearing of change (71-73): the poetic word for "the sea" is $\pi \dot{\lambda} \lambda \alpha \gamma o \zeta$ [pelagos] as the firm grounding of the Greek temple "contrasts with the surge of the surf, and its own repose brings out the raging of the sea" (Heidegger 2000: 89). Beings are gathered in their presencing-together: dwelling is always dwellingnear with your neighbor coming into presence in the immediate neighborhood, a belonging-together as a "constellation" or "archi-pelagos", the elemental sea of beings. This creates a feminine/maternal sense of community and equiprimordiality [gleichursprünglichkeit] in an essential poetic attunement to the self-withholding truth of Being, stirring forth while staying within rest: "the sea and the land and the wilderness are those realms that human beings transform with all their skillfulness, use and make their own, so that they may find their own vicinity through such realms" (Heidegger 1996: 73). This gathering in co-presencing is made possible through a unifying and thoughtful remembrance [Andenken] of the fourfold [Geviert]: "In saving the earth, in receiving the sky, in awaiting the divinities, in initiating mortals, dwelling occurs as the fourfold preservation of the fourfold" (Heidegger 2001: 149). In his reading of Heaney's 'Sunlight' (1998: 93-94) Garrard elaborates: "It is here that mortals 'take place' - in the 'sunlit absence' of a peaceful farm, for instance. Earth gives wheat for flour, while sky gives sun and rain, the time of days and seasons and "calendar customs" (1998: 177). Heaney, as each of the members of his community, "is hooped to where he planted / and sky and ground // are running naturally among his arms / that grope the cropping land" (1998: 51). The mirror-play [Spiegel-spiel] of the fourfold "binds into freedom" the dwelling human beings in their nearness "through the enfolding clasp of their mutual appropriation": "This appropriating mirror-play of the simple onefold of the earth and sky, divinities and mortals, we call the world" (Heidegger 2001: 178-9). Heidegger's "being-with" [Mitsein] and "staying with things" in this single-foldedness reveals the significance of the "lettingbe" of beings [Gelassenheit]: authentic freedom is not freedom "from" the other but freedom "in" being-with-the-other and co-belonging in presencing. Heaney writes: "And drive back home, still with nothing to say / Except that now you will 
uncode all landscapes / By this: things founded clean on their own shapes, / Water and ground in their extremity" (1998: 21).

Dwelling in the bogland, Heaney and his community "step through origins" (1998: 120): the bog is like a horizontal river, with a similar suggestion of existing outside time, at once origin, path and destination. In 'Peninsula', the journeying poet knows that "you will not arrive // But pass through" (21): the continuous, if glacial, crusting of the bog's layers, in a simultaneous act of vanishing and intimation, "goes into what has been and what is to come, yet in such a way that" the bog is "that which has been, and that which is to come as well" (Heidegger 1996: 32). Thus, the bog manifests its "originarily unitary essence" (32) as the threefold ecstatic unity of Dasein's temporality [Zeitlichkeit], of past, present, and future. In this way, the bog is "the journeying of a historical coming to be at home at the locale of this locality" (33) of the dwelling of human beings. It is at once the locality of journeying and the journeying of locality: "You had to come back / To learn how to lose yourself, / To be pilot and stray---witch, / Hansel and Gretel in one" (Heaney 1998: 39). Thus, a poetic time is revealed, beyond metaphysical temporality and calendar dates, as the primordial dimension of time, that of the nearness of beings in their co-presencing, the Light that makes possible the mirror-play of the fourfold.

The last stanza of 'Personal Helicon' reads: "Now, to pry into roots, to finger slime, / To stare, big-eyed Narcissus, into some spring / Is beneath all adult dignity. I rhyme / To see myself, to set the darkness echoing" (Heaney 1966 / 1998: 15). In Ovid's account of the myth of Echo and Narcissus in 'Book III' of The Metamorphoses (1958: 74-80) the turning point of the tragedy is when Narcissus, frustrated with his unrequited self-love, sheds tears on the pool and obscures his own reflection: the youth rips his chest apart with his marmoreal hands, and dies a bloody death. In 'Gifts of Rain' Heaney, "still mammal" and "wading" through flooded marshlands of poetic awakening, encounters a similar image as he "breaks the pane of flood: // a flower of mud- / water blooms up to his reflection // like a cut swaying / its red spoors through a basin" (1998: 50). The death of Narcissus is the death/maturation of Seamus the boy (the 'naturalist'): Heaney changes the focus from Narcissus to Echo, from seeing to hearing, in line with the recent anti-ocularcentric turn in continental philosophy. This distinction between the visual and the audible facilitates a return "to the hither side of the "theoretical threshold" itself" (Lacoue-Labarthe 1989: 145) to question the specularity (reflection, analogy, etc.), which has obsessed philosophical discourse since Plato, at its intersection with what Heidegger calls the pre-theoretical something [Ur-etwas]. Musicality, hence listening, belongs infra-liminally to this primal, pre-worldly, and absolute sea ("archi-pelagos"): "rhythm establishes the break between the visible and the audible, the temporal and the spatial" (199) and is anterior to both speech and writing. According to Heidegger, it is through the sounding of language, as distinguished from verbal sonority, that words become meaningful: "All sounding becomes Be-stimmung: a bringing to voice which fixes language in presence" (Nowell-Smith 2013: 26). It is the sound that makes sense, a fact 
that underscores the motif of "listening with the third ear", first mentioned by Nietzsche, what, according to Theodor Reik, is "the means of detecting the substructures of the soul" and "a subterranean store room of unconscious memorytraces" (quoted in Lacoue-Labarthe 1989: 162). This is perhaps what Heaney does in the lines "if I lie with my ear / in this loop of silence // long enough, thighbone / and shoulder against the phantom ground, // I expect to pick up / a small drumming" (1998: 49). In his critical writings, Heaney uses the phrase "sound of sense": "His poetry," as Parini maintains, "was a divine echo chamber, a place where he listened and watched, gathering what Frost called the 'sound of sense' in a discrete and physical manner, amplifying his own voice by rhymes, working on countless linguistic and symbolic levels" (2018: n.p.)

Music is essentially repetition, and rhythm, as an acoustic phenomenon, is the caesura which makes repetition and hence imitation possible upon the passage into the specular level of theory. The Unheimli(s)ch is brought about as the absence of this rhythm, which "is equivalent to the infinitely paradoxical appearance of the mimetic itself: the indifferentiable as such, the imperceptible par excellence [...] reveals the unrevealable imitation or repetition" (Lacoue-Labarthe 1989: 195). Language is restored to the originary level of a mummer's silent gestures. In the absence of repetition, nothing can happen (in the sense of coming-into-being). Yet, something has to happen for "poetry makes nothing happen: it survives / In the valley of its saying" (Auden 1979: 82; italics added). The authentic poet runs up against "the impossibility of circumscribing the essence of listening" (LacoueLabarthe 1989: 163): in order to bring forth his poetic work from the abyss of the nothing into the light of being, he has to step back into the specular, and resort again to "theoretical or theorizing figures of repetition, of the reactivation of the trace" (165), such as reflections and echoes. However, this time, he has listened with a third ear to the darkness, and is privy to the concealment of its enigma: "I rhyme / to see myself, to set the darkness echoing" (Heaney 1998: 15). In grafting the scopic with the acoustic, Heaney has found the singular "rhythm" that slowly brings him into his "proper haunt" (157).

Heaney's personal Helicon is Echo's cave. He retires and dwells there within a feminine-maternal, pre-reflective space of intra-uterine memory-traces, where he can listen authentically, that is, become attentive to the voice distilling from Echo's bones, echoing perpetually off the walls - the Voice of Being. This elemental voice gathers lovers, in Reik's words, according to "the temporal concordance of the individual rhythm of two human beings" (quoted in Lacoue-Labarthe 1989: 198): "Yesterday rocks sang when we tapped / Stalactites in the cave's old, dripping dark - / Our love calls tiny as a tuning fork" (Heaney 1998: 71).

\section{Notes}

For a major deconstructive view of Heaney's approach to Irish politics see O'Brien (2003), particularly Chapter 4: “Surviving Amphibiously': Poetry and Politics' (81-111); O'Brien, Eugene (2009) “Inner Émigré(s)': Derrida, Heaney, Yeats and the Hauntological Redefinition 
of Irishness.' In: 'Kicking Bishop Brennan Up the Arse': Negotiating Texts and Contexts in Contemporary Irish Studies. Bern: Peter Lang, 97-110.

2 For scholarship on the influence of Romanticism on Yeats, particularly his encounters with Shelley and Blake, see Bornstein, George (2006) 'Yeats and Romanticism.' In: Howes, Marjorie and John Kelly (eds.) The Cambridge Companion to W. B. Yeats. Cambridge: Cambridge University Press, 19-35.

\section{References}

Auden, W. H. (1979) 'In Memory of W. B. Yeats.' In: Mendelson, Edward (ed.) W. H. Auden: Selected Poems. New York: Vintage Books, 80-83.

Clark, Timothy (1986) "Being in Mime: Heidegger and Derrida on the Ontology of Literary Language.' MLN 101(5), 1003-1021.

Deleuze, Gilles (1994) Difference and Repetition. Transl. by Paul Patton. New York: Columbia University Press.

De Man, Paul (1983) 'Heidegger's Exegeses of Hölderlin.' In: Blindness and Insight: Essays in the Rhetoric of Contemporary Criticism. Minneapolis: University of Minnesota Press, 246-266.

Derrida, Jacques (1981) 'The Double Session.' In: Dissemination. Transl. by Barbara Johnson, 173-285. London: The Athlone Press.

Derrida, Jacques (1989) Of Spirit: Heidegger and the Question. Transl. by Geoffrey Bennington and Rachel Bowlby. Chicago \& London: The University of Chicago Press.

Garrard, Greg (1998) 'Heidegger, Heaney and the problem of dwelling.' In: Kerridge, Richard and Neil Sammells (eds.) Writing the Environment: Ecocriticism and Literature. London: Zed Books, 167-181.

Harries, Karsten (1976) ‘Language and Silence: Heidegger's Dialogue with Georg Trakl.' boundary $24(2), 495-511$.

Heaney, Seamus (1972) Wintering Out. London: Faber \& Faber.

Heaney, Seamus (1980) Preoccupations: Selected Prose, 1968-1978. London: Faber \& Faber.

Heaney, Seamus (1988) 'The Placeless Heaven: Another Look at Kavanagh.' In: The Government of the Tongue: Selected Prose, 1978-1987. New York: Farrar, Straus and Giroux, 3-14.

Heaney, Seamus (1998) Opened Ground: Poems 1966-1996. New York: Faber \& Faber.

Heidegger, Martin (1956) 'The Way Back into the Ground of Metaphysics.' In: Existentialism: From Dostoevsky to Sartre. Ed. and transl. by Walter Kaufmann. New York: Meridian Books, 206-221.

Heidegger, Martin (1968) What Is Called Thinking? Transl. by J. Glenn Grey. New York: Harper \& Row.

Heidegger, Martin (1971) On the Way to Language. Transl. by Peter D. Hertz. New York: Harper \& Row.

Heidegger, Martin (1996) Hölderlin's Hymn “The Ister.” Transl. by William McNeill and Julia Davis. Bloomington and Indianapolis: Indiana University Press.

Heidegger, Martin (2000) 'The Origin of the Work of Art.' Transl. by Albert Hofstadter. In: Cazeaux, Clive (ed.) The Continental Aesthetics Reader. New York \& London: Routledge, 80-101.

Heidegger, Martin (2001) Poetry, Language, Thought. Transl. by Albert Hofstadter. New York: Perennial Classics.

Heidegger, Martin (2012) Contributions to Philosophy: Of the Event. Transl. by Richard Rojcewicz and Daniela Vallega-Neu. Bloomington and Indianapolis: Indiana University Press.

Kelkel, Arion L. (1997) 'Language after Husserl.' Transl. by Lester Embree. In: Embree, Lester et al. (eds.) Encyclopedia of Phenomenology. Dordrecht: Springer Science \& Business Media, 394-401.

Lacoue-Labarthe, Philippe (1989) 'The Echo of the Subject.' In: Typography: Mimesis, Philosophy, Politics. Transl. and ed. by Christopher Fynsk. Cambridge, MA: Harvard University Press, 139-208. 
Longley, Edna (1992) “Inner Émigré' or 'Artful Voyeur'? Seamus Heaney’s North.' In: Andrews, Elmer (ed.) Seamus Heaney: A Collection of Critical Essays. New York: St. Martin's Press.

MacKay, Peter (2009) 'Memory, the Bog, Seamus Heaney.' ecloga 7, 80-97.

Malone, Christopher T. (2000) 'Writing Home: Spatial Allegories in the Poetry of Seamus Heaney and Paul Muldoon.' ELH 67(4), 1083-1109.

Nowell-Smith, David (2013) 'Sounding/Silence.' Gatherings: The Heidegger Circle Annual 3, $18-29$.

O’Brien, Eugene (2003) Seamus Heaney: Searches for Answers. London: Pluto Press.

Ovid (1958) 'Book III.' In: The Metamorphoses. Transl. and with an introduction by Horace Gregory. New York: The Viking Press, 62-89.

Parini, Jay (2018) 'Seamus Heaney: Putting Feelings into Words.' The Telegraph, 14 March. https:// www.telegraph.co.uk/culture/books/10288645/Seamus-Heaney-putting-feelings-into-words. html (accessed on 11 April 2018).

Purdy, Anthony (2002) 'The Bog Body as Mnemotope: Nationalist Archaeologies in Heaney and Tournier.' Style 36(1), 93-110.

Ramazani, Jahan (1994) Poetry of Mourning: The Modern Elegy from Hardy to Heaney. Chicago: University of Chicago Press.

Regan, Stephen (2014) “"Things Remembered": Objects of Memory in the Poetry of Seamus Heaney.' Eire-Ireland 49(3\&4), 320-336.

Schmidt, A. V. C. (1985) “Darkness Echoing': Reflections on the Return of Mythopoeia in Some Recent Poems of Geoffrey Hill and Seamus Heaney.' RES New Series XXXVI. (142), 199-225.

Thomson, Iain (2015) 'Heidegger's Aesthetics.' Zalta, Edward N. (ed.) The Stanford Encyclopedia of Philosophy, 26 June. https://plato.stanford.edu/archives/fall2015/entries/heidegger-aesthetics/ (accessed on 2 September 2017).

Watson, George (2006) 'Yeats, Victorianism, and the 1890s.' In: Howes, Marjorie and John Kelly (eds.) The Cambridge Companion to W. B. Yeats. Cambridge: Cambridge University Press. 3658 .

KAMRAN AHMADGOLI holds a PhD in English from the University of Birmingham in the UK. $\mathrm{He}$ is currently a member of academic staff at the Department of Foreign Languages, Kharazmi University, Tehran, Iran. He carries out research and conducts courses in the philosophy of literature and American and Anglo-Irish poetry at Kharazmi.

Address: Asst. Prof. Dr Kamran Ahmadgoli, Faculty of Humanities, Department of Foreign Languages, Kharazmi University, Tehran, 43 South Mofatteh Ave., 15719-14911, Tehran, Iran. [email: ahmadgoli@khu.ac.ir; k.ahmadgoli@gmail.com]

SEYED-NIMA TAHERI-AZAM holds an MA in English from Kharazmi University, Tehran, and is currently a PhD candidate of English at the department of Foreign Languages at Kharazmi. He is interested in the philosophy of literature and American and Anglo-Irish poetry and fiction.

Address: Seyed-Nima Taheri-Azam, Faculty of Humanities, Department of Foreign Languages, Kharazmi University, Tehran, 43 South Mofatteh Ave., 15719-14911, Tehran, Iran. [email: std_ nima_taheri@khu.ac.ir] 